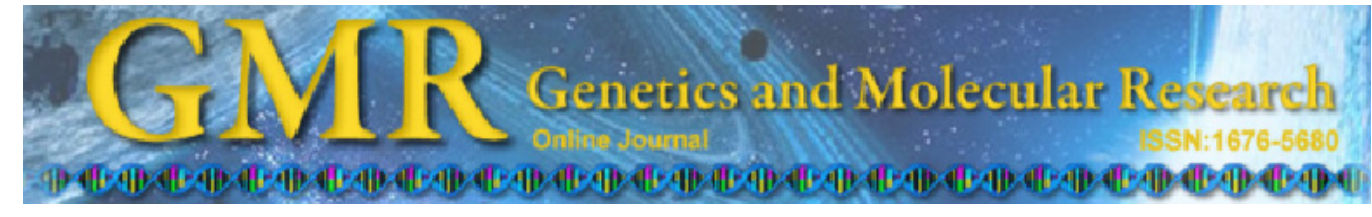

\title{
Genetic diversity among melon accessions (Cucumis melo) from Turkey based on SSR markers
}

\author{
Y.A. Kaçar, O. Simsek, I. Solmaz, N. Sari and Y.Y. Mendi \\ Department of Horticulture, Faculty of Agriculture, University of Cukurova, \\ Adana, Turkey \\ Corresponding author: Y.A. Kaçar \\ E-mail: ykacar@cu.edu.tr
}

Genet. Mol. Res. 11 (4): 4622-4631 (2012)

Received May 4, 2012

Accepted September 25, 2012

Published November 29, 2012

DOI http://dx.doi.org/10.4238/2012.November.29.2

\begin{abstract}
Melon (Cucumis melo) is an important vegetable crop in Turkey, where it is grown in many regions; the most widely planted lines are local winter types belonging to the var. inodorous. We examined 81 melon genotypes collected from different provinces of Turkey, compared with 15 reference melon genotypes obtained from INRA/France, to determine genetic diversity among Turkish melons. Twenty polymorphic primers were used to generate the SSR markers. PCR amplification was performed and electrophoresis was conducted. SSR data were used to generate a binary matrix. For cluster analysis, UPGMA was employed to construct a clustering dendrogram based on the genetic distance matrix. The cophenetic correlation was compared with the similarity matrix using the Mantel matrix correspondence test to evaluate the representativeness of the dendrogram. A total of 123 alleles were amplified using the 20 SSR primer sets. The number of alleles detected by a single primer set ranged from 2 to 12 , with an average of 6.15 . The similarity ranged from 0.22 to 1.00 in the dendrogram developed from microsatellite analysis. Based on this molecular data, we concluded that genetic diversity among these Turkish accessions is relatively high.
\end{abstract}

Key words: Cucumis melo; Genetic resources; Microsatellite analysis; Genetic diversity 


\section{INTRODUCTION}

Melon (Cucumis melo L.) is a temperate and warm season crop belonging to the genus Cucumis in the family Cucurbitaceae. It is considered to be the most diverse species, and several intraspecific classifications have been reported (Robinson and Decker-Walters, 1997; Nuñez-Palenius et al., 2008; Szamosi et al., 2010). Recently, Pitrat et al. (2000) classified melons into 16 groups, 5 of which (conomon, makuwa, chinensis, momordica, and acidilus) can be assigned to the subsp agrestis and 11 (cantalupensis, reticulatus, adana, chandalak, ameri, inodorus, flexuosus, chate, tibish, dudaim, and chito) to the subsp melo. As stated by McCreight et al. (1993), var. cantalupensis and var. inodorus are the most economically significant melons grown in the US and in European, Mediterranean and Asian countries.

Turkey is the second leading country after China in melon production, with 1749 million tons of melon grown (FAO, 2009). The country is also located in a secondary genetic diversity center (Pitrat et al., 1999). Turkey has been reported to be rich in melon genetic resources, as Turkish melons are morphologically diverse, especially in regard to fruit traits (Sari and Solmaz, 2007; Sensoy et al., 2007; Solmaz et al., 2010). However, these valuable genetic resources are being compromised by the cultivation of commercial varieties that have a higher yield and are of better quality. Due to environmental and economic factors, the local landraces are likely to become extinct in the near future. Nevertheless, Turkish melon strains potentially have useful genes that can be utilized in breeding programs.

As stated by Escribano and Lázaro (2009), morphological analyses are an absolute requirement for the initial evaluation of genetic resources and the accurate identification of local landraces. Several studies have morphologically characterized local germplasms and found them to represent different genetic sources (Decker-Walters et al., 2002; Liu et al., 2004; Staub et al., 2004; Laghetti et al., 2008; Escribano and Lázaro, 2009; Szamosi et al., 2010). Molecular markers have been shown to be useful to assess genetic diversity in a number of plant species (Bretting and Widrlechner, 1995; Staub et al., 2000). These molecular markers provide complete morphological and phonological data because they are plentiful, free of tissue and environmental factors and allow for cultivar identification in the early stages of development. Esquinas-Alcazar (1977) used isozymes to perform the preliminary study of melon to determine genetic relationships. In 1996, Katzir et al. (1996) developed the first simple sequence repeats (SSR) markers in melons. Molecular characterization of melons was performed using techniques including cleaved amplified polymorphic sequences (Zheng et al., 1999), amplified fragment length polymorphism (Garcia-Mas et al., 2000), random amplified polymorphic DNA (RAPD) (Stepansky et al., 1999; Mliki et al., 2001; Staub et al., 2004; Nakata et al., 2005; Sensoy et al., 2007; Tanaka et al., 2007) and SSR (Danin-Poleg et al., 2001; Szabo et al., 2008; Tzitzikas et al., 2009). Several additional studies compared different types of molecular markers to determine the genetic diversity of melons. Silberstein et al. (1999) revealed molecular variation by restriction fragment length polymorphism and RAPD, Stepansky et al. (1999) used RAPD and inter-simple sequence repeat for intraspecific classification; López-Sesé et al. (2002) assessed between and within accession variation in Spanish melon germplasm by RAPD and SSR; Staub et al. (2000) used both RAPD and SSR markers to characterize melon groups and reported that lower coefficients of variation can be attained when using RAPDs compared to SSRs, and Nakata et al. (2005) assessed the genetic diversity of Japanese melon cultivars by RAPD and SSR markers. Additionally, 
morphological and molecular (SSR, ITS) characterization of 47 melon genotypes was carried out to determine an extinct medieval type (Szabo et al., 2008).

SSR markers, represented by the repeats of 1-6 nucleotide-long DNA motifs arranged in tandem, have been considered one of the most powerful Mendelian markers (Jarne and Lagoda, 1996) because of their high reproducibility, co-dominance inheritance, multi-allelic character, and extensive genome coverage (Powell et al., 1996). The polymorphism of SSRs, primarily resulting from the variation of repeat numbers, can be easily detected by a simple PCR technique. Together, these features are advantageous for genetic mapping, quantitative trait loci association, population genetics, and evolutionary studies (Hu et al., 2010).

The aim of this study was to determine the genetic diversity of melon genotypes collected from different provinces of Turkey compared with reference genotypes representing different melon varieties using SSR markers.

\section{MATERIAL AND METHODS}

This study was carried out in the Department of Horticulture, Faculty of Agriculture, University of Cukurova, Turkey.

\section{Plant material}

A total of 96 melon genotypes were used as plant material. Eighty-one melon genotypes were collected from different provinces of Turkey and 15 reference genotypes were obtained from INRA/France (Table 1).

\section{DNA isolation}

Young leaves were collected from each melon genotype and immediately frozen in liquid nitrogen and stored at $-80^{\circ} \mathrm{C}$. High molecular weight genomic DNA was extracted from the leaf samples following the CTAB miniprep protocol (Edwards et al., 1991). DNA concentration was measured with a NanoDrop ND 100 spectrophotometer (NanoDrop Technologies, Inc.) and gel electrophoresis. DNA was diluted in water to a final concentration of $50 \mathrm{ng} / \mu \mathrm{L}$ and stored at $-20^{\circ} \mathrm{C}$.

\section{SSR analysis}

Twenty primers (CMCT44, CMGA104, CMACC146, CMCTT144, CMTC47, CMAT141, CMCCA145, CMTC168, CMGA172, CMTC123, CMTG108, CMTAA166, CMTA134a, CMTC160a+b, CSCTTT15a, CMGAN92, CMGAN10, CMGAN59, CMGAN68, and TJ24) were used to generate the SSR markers. Amplification reactions were performed in $10-\mu \mathrm{L}$ volumes containing $2 \mathrm{X}$ PCR Mastermix (Fermentas K0171), 1 $\mathrm{U}$ Taq DNA polymerase (Fermentas EP0402), $25 \mathrm{mM} \mathrm{MgCl}_{2}, 1 \mu \mathrm{M}$ forward and reverse primers and $25 \mathrm{ng}$ melon DNA. The mixtures were prepared at $0^{\circ} \mathrm{C}$ and transferred to the thermal cycler. The amplification was performed in a model Master Gradient thermal cycler (Eppendorf) using a program consisting of an initial denaturation step of $2 \mathrm{~min}$ at $94^{\circ} \mathrm{C}$ followed by 35 cycles of $2 \mathrm{~min}$ at $94^{\circ} \mathrm{C}, 1 \mathrm{~min}$ at $55^{\circ} \mathrm{C}$ and $2 \mathrm{~min}$ at $72^{\circ} \mathrm{C}$; the program ended 
Table 1. Melon germplasms used in this study.

\begin{tabular}{|c|c|c|c|c|}
\hline No. & Genotype & Local name & Origin & Horticultural variety (group) \\
\hline 1 & KAV 1 & Asma kavunu & Diyarbakır & var. inodorus \\
\hline 2 & KAV 3 & Unnamed & Mardin & var. inodorus \\
\hline 3 & KAV 5 & Unnamed & Şanlıurfa & var. inodorus \\
\hline 4 & KAV 8 & Unnamed & Şanlıurfa & var. inodorus \\
\hline 5 & KAV 19 & Unnamed & Gaziantep & var. inodorus \\
\hline 6 & KAV 26 & Kışlık kavun & İzmir & var. inodorus \\
\hline 7 & KAV 27 & Gönen kavunu & Bursa & var. inodorus \\
\hline 8 & KAV 28 & Melemen kavunu & Manisa & var. inodorus \\
\hline 9 & KAV 29 & Çengel Tatar kavunu & Manisa & var. inodorus \\
\hline 10 & KAV 36 & Unnamed & Ușak & var. inodorus \\
\hline 11 & KAV 37 & Unnamed & İstanbul & var. inodorus \\
\hline 12 & KAV 39 & Lambada kavunu & Manisa & var. inodorus \\
\hline 13 & KAV 40 & Dilim kavunu & Manisa & var. inodorus \\
\hline 14 & KAV 42 & Unnamed & Tekirdağ & var. inodorus \\
\hline 15 & KAV 43 & Unnamed & Tekirdağ & var. inodorus \\
\hline 16 & KAV 45 & Sülüklü kışlık kavun & Tekirdağ & var. inodorus \\
\hline 17 & KAV 46 & Unnamed & Uşak & var. inodorus \\
\hline 18 & KAV 48 & Unnamed & Uşak & var. inodorus \\
\hline 19 & KAV 50 & Cavdan kavunu & Manisa & var. inodorus \\
\hline 20 & KAV 51 & Unnamed & Balıkesir & var. inodorus \\
\hline 21 & KAV 52 & Acur kavunu & Balikesir & var. inodorus \\
\hline 22 & KAV 54 & Siyah kavun & Manisa & var. inodorus \\
\hline 23 & KAV 56 & Unnamed & Çanakkale & var. inodorus \\
\hline 24 & KAV 59 & Girnogi & Adiyaman & var. inodorus \\
\hline 25 & KAV 61 & Bal kavunu & Adiyaman & var. inodorus \\
\hline 26 & KAV 62 & Kelek bal kavun & Adiyaman & var. inodorus \\
\hline 27 & KAV 64 & Şemamok & Mardin & var. dudaim \\
\hline 28 & KAV 65 & Şelengo & Şanlıurfa & var. cantalupensis \\
\hline 29 & KAV 66 & Yabani kavun & Şanlıurfa & var. agrestis \\
\hline 30 & KAV 67 & Unnamed & Ankara & var. inodorus \\
\hline 31 & KAV 70 & Kuşçular & Unknown & var. inodorus \\
\hline 32 & KAV 71 & Yabani & Unknown & var. agrestis \\
\hline 33 & KAV 72 & Unnamed & Sakarya & var. inodorus \\
\hline 34 & KAV 73 & Unnamed & Şanlıurfa & var. inodorus \\
\hline 35 & KAV 74 & Unnamed & Unknown & var. inodorus \\
\hline 36 & KAV 79 & Unnamed & Ankara & var. inodorus \\
\hline 37 & KAV 82 & Unnamed & Uşak & var. inodorus \\
\hline 38 & KAV 84 & Unnamed & Manisa & var. inodorus \\
\hline 39 & KAV 85 & Unnamed & Nevşehi & var. inodorus \\
\hline 40 & KAV 87 & Unnamed & Niğde & var. inodorus \\
\hline 41 & KAV 90 & Unnamed & Elazı̆ & var. inodorus \\
\hline 42 & KAV 170 & Unnamed & Antalya & var. inodorus \\
\hline 43 & KAV 171 & $90625 / \mathrm{C} 9 \mathrm{C} 2$ & INRA, France & var. acidulous \\
\hline 44 & KAV 173 & Carosello & INRA, France & var. chate \\
\hline 45 & KAV 174 & Chandaljak & INRA, France & var. chandalak \\
\hline 46 & KAV-175 & ME $0705=$ Cuba 1 & INRA, France & var.chito \\
\hline 47 & KAV-176 & ME 0733 = Fazaizabadi & INRA, France & var. flexuosus \\
\hline 48 & KAV 177 & Honeydew Green Flesh & INRA, France & var. inodorus \\
\hline 49 & KAV 179 & Khatoni & INRA, France & var. ameri \\
\hline 50 & KAV 180 & MR 1 & INRA, France & var. momordica \\
\hline 51 & KAV 183 & PI 414723/TG & INRA, France & var. momordica \\
\hline 52 & KAV 186 & Queen's Pocket Melon & INRA, France & var. dudaim \\
\hline 53 & KAV-187 & ME $0241=$ Shiro Uri Okayama & INRA, France & var. conomon \\
\hline 54 & KAV 188 & Snakemelon & INRA, France & var. flexuosus \\
\hline 55 & KAV 189 & Tibish 93-2 & INRA, France & var. tibish \\
\hline 56 & KAV 190 & Vedrantais & INRA, France & var. cantalupensis \\
\hline 57 & KAV 191 & Unnamed & Kahramanmaraş & var. inodorus \\
\hline 58 & KAV 213 & Tirtıllı kara kavun & Ankara & var. inodorus \\
\hline 59 & KAV 214 & Altınbaş & Ankara & var. inodorus \\
\hline 60 & KAV 221 & Kışlık sarı kavun & Ankara & var. inodorus \\
\hline 61 & KAV 226 & Altın & Ankara & var. inodorus \\
\hline
\end{tabular}




\begin{tabular}{|c|c|c|c|c|}
\hline No. & Genotype & Local name & Origin & Horticultural variety (group) \\
\hline 62 & KAV 228 & Uzun yuva & Ankara & var. inodorus \\
\hline 63 & KAV 232 & Çikolata & Ankara & var. inodorus \\
\hline 64 & KAV 234 & İpsala & Ankara & var. inodorus \\
\hline 65 & KAV 235 & Mühürlü siyah kavun & Ankara & var. inodorus \\
\hline 66 & KAV 237 & Portakal kavun & Ankara & var. inodorus \\
\hline 67 & KAV 239 & Dilimli & Ankara & var. inodorus \\
\hline 68 & KAV 242 & Yerli kavun (muz kavunu) & Ankara & var. inodorus \\
\hline 69 & KAV 249 & Kırkağaç & Ankara & var. inodorus \\
\hline 70 & KAV 250 & Şememe & Ankara & var. dudaim \\
\hline 71 & KAV 252 & Tepeköy kavunu & Ankara & var. inodorus \\
\hline 72 & KAV 255 & Kışlık kavun & Konya & var. inodorus \\
\hline 73 & KAV 265 & Unnamed & Erzurum & var. inodorus \\
\hline 74 & KAV 266 & Unnamed & Erzurum & var. inodorus \\
\hline 75 & KAV 267 & Unnamed & Erzurum & var. inodorus \\
\hline 76 & KAV 269 & Unnamed & Erzurum & var. inodorus \\
\hline 77 & KAV 274 & Unnamed & Erzurum & var. inodorus \\
\hline 78 & KAV 277 & Unnamed & Erzurum & var. inodorus \\
\hline 79 & KAV 278 & Unnamed & Erzurum & var. inodorus \\
\hline 80 & KAV 279 & Unnamed & Erzurum & var. inodorus \\
\hline 81 & KAV 280 & Unnamed & Erzurum & var. inodorus \\
\hline 82 & KAV 282 & Kış kavunu & Elazığ & var. inodorus \\
\hline 83 & KAV 284 & Malbora kavunu & Elazığ & var. inodorus \\
\hline 84 & KAV 287 & Kışlık beyaz kavun & Elazığ & var. inodorus \\
\hline 85 & KAV 291 & VA435 & INRA, France & var. cantalupensis \\
\hline 86 & KAV 292 & Yabani & Mersin & var. agrestis \\
\hline 87 & $\mathrm{AC} 01$ & Beyaz Acur Kisa Meyve & Ankar & var. flexuosus \\
\hline 88 & $\mathrm{AC} 05$ & Hitta & Şanliurfa & var. flexuosus \\
\hline 89 & $\mathrm{AC} 07$ & Kızılören 1 & Kayseri & var. flexuosus \\
\hline 90 & AC 16 & Adana & Adana & var. flexuosus \\
\hline 91 & AC 33 & TR 47808 & İzmir & var. flexuosus \\
\hline 92 & $\mathrm{AC} 47$ & TR 51559 & İzmir & var. flexuosus \\
\hline 93 & AC 51 & Hitta & Şanlıurfa & var. flexuosus \\
\hline 94 & AC 54 & Unnamed & Siirt & var. flexuosus \\
\hline 95 & AC 56 & Unnamed & Nevşehir & var. flexuosus \\
\hline 96 & $\mathrm{AC} 60$ & Tüylü Acur & Şanlıurfa & var. flexuosus \\
\hline
\end{tabular}

with a 10 -min elongation step at $72^{\circ} \mathrm{C}$. PCR products were stored at $4{ }^{\circ} \mathrm{C}$ prior to analysis. After amplification, 1-25 $\mu \mathrm{L}$ of loading buffer containing 95\% formamide, $10 \mathrm{mM}$ EDTA, $\mathrm{pH} 8.0,0.025 \%$ xylene cyanol, and $0.025 \%$ bromophenol blue were added to each reaction tube. The samples were heat-denatured for $5 \mathrm{~min}$ at $95^{\circ} \mathrm{C}$ and quickly transferred to ice. After loading $1.0 \mu \mathrm{L}$ of each sample, PCR products were separated on $6 \%$ denaturing polyacrylamide gel that had been preheated for $25 \mathrm{~min}$. Electrophoresis was conducted at 1500 $\mathrm{V}, 50 \mathrm{~W}, 35 \mathrm{~mA}$, and $48^{\circ} \mathrm{C}$ using a Li-Cor DNA Analyzer 4300. A 50-350 bp DNA ladder (MWG Biotech AG, Ebersberg, Germany) was run alongside the amplified PCR products to determine DNA sizes.

SSR data were coded with a 1 to indicate the presence of a band or 0 to indicate its absence for the generation of a binary matrix. For cluster analysis, the clustering procedure unweighted pair-group method using the arithmetic average (UPGMA) was employed to construct the clustering dendrogram based on the genetic distance matrix using the NTSYS-PC version 2.02i program (Rohlf, 1998). The Mantel matrix correspondence test (Mantel, 1967) was used to evaluate the representativeness of the dendrogram by estimating the cophenetic correlation for the dendrogram compared with the similarity matrix. The result of this test is a cophenetic correlation coefficient, $r$, indicating how well the dendrogram represents similarity data. 


\section{RESULTS AND DISCUSSION}

Genetic diversity among Turkish melon genotypes was evaluated by SSR markers. Amplification was successful with 20 markers assayed. A total of 123 alleles were generated using the 20 SSR primer sets listed in Table 2. The polymorphism rate was $97.5 \%$ among 96 genotypes. The number of alleles detected by a single primer set ranged from 2 to 12 , with an average of 6.15 (Table 2). This average was higher than those of many previous reports. Tzitzikas et al. (2009) used SSR markers to investigate the genetic diversity and population structure of traditional Greek and Cypriot melon cultigens. They reported that all SSR markers were polymorphic with a total number of 81 alleles, averaging 4.7 alleles per locus. In another study, a total of 232 SSR alleles and an average of 10.3 alleles per SSR were obtained for Indian snap melons (C. melo var. momordica) (Dhillon et al., 2007). Kong et al. (2007) used EST-SSR markers in C. melo and found that the number of alleles ranged from 2 to 5 with an average of 2.9 alleles per locus.

\section{Table 2. Simple sequence repeat marker bands used to assess the genetic diversity of melons.}

\begin{tabular}{|c|c|c|c|c|}
\hline No. & Primer & Size (bp) & Polymorphic band No. & Polymorphism (\%) \\
\hline 1 & СMCT44 & $130,140,143,145,148,150,152,154,156,158,175$ & 11 & 100 \\
\hline 2 & CMGA104 & $161,164,170,173,176,180,182,184$ & 8 & 100 \\
\hline 3 & CMACC146 & $155,160,170$ & 3 & 100 \\
\hline 4 & CMCTT144 & $185,198,200,207,210,212,215,218$ & 8 & 100 \\
\hline 5 & CMTC47 & $172,175,185,190$ & 4 & 100 \\
\hline 6 & CMAT141 & $185,187,190,195,198$ & 5 & 100 \\
\hline 7 & CMCCA145 & $145,148,150,173$ & 4 & 100 \\
\hline 8 & CMTC168 & $200,208,210,215,218,220$ & 6 & 100 \\
\hline 9 & CMGA172 & $125,130,132,138,142,145$ & 6 & 100 \\
\hline 10 & CMTC123 & 122,125 & 1 & 50 \\
\hline 11 & CMTG108 & $204,206,208$ & 3 & 100 \\
\hline 12 & CMTAA166 & $170,180,185,200,204,206$ & 6 & 100 \\
\hline 13 & CMTA134a & $165,166,170,173,180,190,200,202,210,225,250,255$ & 12 & 100 \\
\hline 14 & CMTC160a+b & $232,235,240,245,250$ & 5 & 100 \\
\hline 15 & CSCTTT15a & 204,206 & 2 & 100 \\
\hline 16 & CMGAN92 & $160,170,176$ & 3 & 100 \\
\hline 17 & CMGAN10 & $183,184,190,195,204,208,218,220$ & 8 & 100 \\
\hline 18 & CMGAN59 & $71,74,76,81,85,86,87,88,91,94$ & 10 & 100 \\
\hline 19 & CMGAN68 & $123,125,128,131,136,140,144$ & 7 & 100 \\
\hline 20 & $\mathrm{TJ} 24$ & $150,156,157,160,174,180,182,185,189,197$ & 10 & 100 \\
\hline Total & & & 122 & 97.5 \\
\hline
\end{tabular}

The results showed that the SSR polymorphism rate (97.5\%) was higher than that reported in much of the literature [71\%, Katzir et al. (1996); 86\%, Danin-Poleg et al. (2001); and 66.7\%, López-Sesé et al. (2002)]. The reason for obtaining high SSR polymorphism values may be due to the large number of genotypes used and the detection of a higher number of alleles, as explained by Monforte et al. (2003).

The matrix correlation coefficient was calculated to be $r=0.94$ for the dendrogram obtained based on the SSR analysis. This value indicates that the similarity index is well represented in the dendrogram (Rohlf, 1998). Interpretation of the correlation coefficient matrix was as follows: $r \geq 0.9$, very good; $0.8 \leq r<0.9$, good; $0.7 \leq r<0.8$, poor; $r<0.7$, very poor.

The similarity coefficient ranged from 0.22 to 1.00 as a result of microsatellite analysis. UPGMA employing SSR data resulted in a dendrogram with two main branches as shown in Figure 1. The genotypes were determined to be highly variable, up to $80 \%$. 


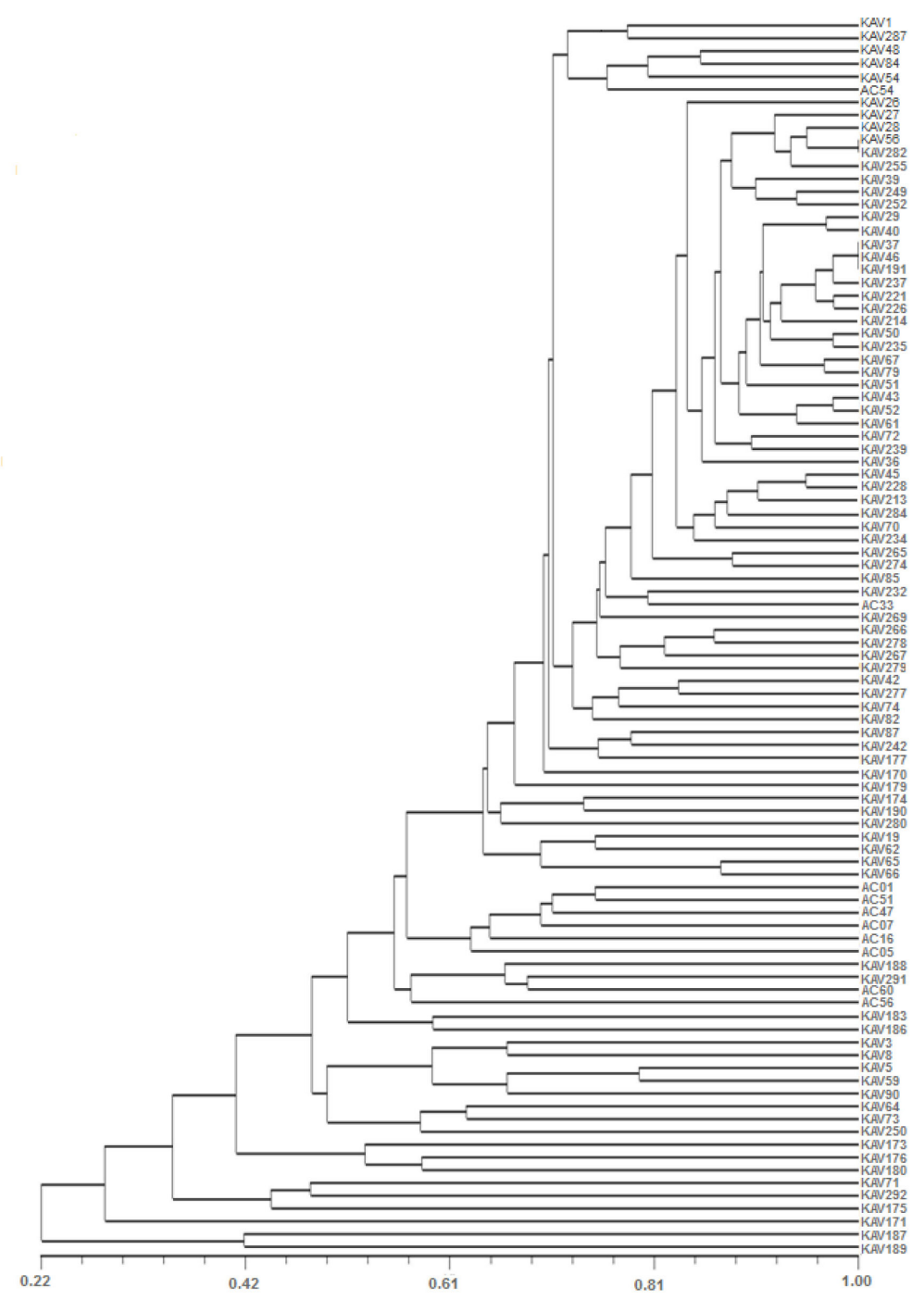

Figure 1. Dendrogram based on simple sequence repeat analysis of 96 melon genotypes.

One of the primary branches of the dendrogram consisted of two reference genotypes (Kav 189 var. tibish and Kav 187 var. conomon) provided by INRA France. However, the similarity coefficient was relatively low $(42 \%)$ because they belong to different botanical groups. The second main branch contained all the other 94 genotypes. SSR analysis supports the separation of reference accessions and Turkish landraces with some exceptions. Most of the snakemelon genotypes, belonging to var. flexuosus, were clustered with the reference accessions as expected.

Based on the results, wild genotypes (Kav 66, Kav 71 and Kav 292), collected from different provinces of Turkey and belonging to var. agrestis, were dispersed among the reference accessions. 
Cluster analysis also indicated that there was no correlation between grouping and geographical origin of the genotypes.

It was obvious that genotypes belonging to the cantalupensis and inodorus varieties were clustered together in different subgroups with varying (70-100\%) similarity rates. These subgroups contained Kirkagac, Yuva, Kuscular, and different local melons, which are morphologically different. In these subgroups, Kav 56 and Kav 282 were identical and classified in var. inodorus. These genotypes are known as the Kirkagac type, which is characterized by an orange rind with green spots. Kav 37, Kav 46 and Kav 191 could not be distinguished from each other as well. This result is consistent with the study of Tzitzikas et al. (2009), in which Greek and Cypriot traditional cultigens were classified within the subspecies melo and found to be different from the flexuosus accessions. Another study, by Staub et al. (2004), used RAPD markers and did not show a distinction between Greek flexuosus landraces and Greek inodorus landraces. The authors speculated that their results were attributed to using a different germplasm or to the discrimination power of the marker type. Genetic differences depending on the marker system were also reported by Staub et al. (2000), Nakata et al. (2005) and Aierken et al. (2011), indicating that the ability of SSR markers to discriminate was better than that of RAPD markers.

The genetic diversity of Turkish melons based on phenotypic characters and RAPD markers was investigated by Sensoy et al. (2007). These researchers reported that the genetic variation among Turkish melon genotypes was very high. This finding is in concordance with our finding of high genetic diversity using SSR markers.

\section{CONCLUSIONS}

Turkey is a secondary center of origin of melons, and it has important melon genetic resources. The present study used SSR markers to detect high genetic variation among the melon genotypes collected from different Turkish provinces. Genetic resources and their conservation and utilization are very important for breeding new cultivars. The genetic resources provided by the diverse melon genotypes in Turkey indicate that Turkey can play an important role in future breeding strategies with these genotypes as candidates for breeding lines.

\section{ACKNOWLEDGMENTS}

Research supported by the Scientific and Technological Research Council of Turkey (TÜBİTAK) (Bosphorus-106 T 616).

\section{REFERENCES}

Aierken Y, Aierken Y, Nhi PTP, Halidan Y, et al. (2011). Molecular analysis of the genetic diversity of Chinese Hami Melon and its relationship to the melon germplasm from Central and South Asia. J. Jpn. Soc. Hort. Sci. 80: 52-65.

Bretting PK and Widerlechner MP (1995). Genetic markers and horticultural germplasm management. HortScience 30: 1349-1356.

Danin-Poleg Y, Reis N, Tzuri G and Katzir N (2001). Development and characterization of microsatellite markers in Cucumis. Theor. Appl. Genet. 102: 61-72.

Decker-Walters DS, Straub JE, Chung SM, Nakata E, et al. (2002). Diversity in free-living populations of Cucurbita pepo (Cucurbitaceae) as assessed by random amplified polymorphic DNA. Syst. Bot. 27: 19-28.

Dhillon NPS, Ranjana R, Singh K, Eduardo I, et al. (2007). Diversity among landraces of Indian snapmelon (Cucumis 
melo var. momordica). Genet. Resour. Crop Evol. 54: 1267-1283.

Edwards K, Johnstone C and Thompson C (1991). A simple and rapid method for the preparation of plant genomic DNA for PCR analysis. Nucleic Acids Res. 19: 1349.

Escribano S and Lázaro A (2009). Agro-morphological diversity of Spanish traditional melons (Cucumis melo L.) of the Madrid provenance. Genet. Resour. Crop Evol. 56: 481-497.

Esquinas-Alcazar JT (1977). Alloenzyme Variation and Relationships in the Genus Cucumis. PhD thesis, University California, Davis.

FAO (2009). Food and Agricultural Organization. Available at [www.fao.org]. Accessed 2011.

Garcia-Mas J, Oliver M, Gómez-Paniagua H and de Vicente MC (2000). Comparing AFLP, RAPD and RFLP markers for measuring genetic diversity in melon. Theor. Appl. Genet. 101: 860-864.

Hu J, Zhou X and Li J (2010). Development of novel EST-SSR markers for cucumber (Cucumis sativus) and their transferability to related species. Sci. Hortic. 125: 534-538.

Jarne P and Lagoda PJL (1996). Microsatellites, from molecules to populations and back. Trends Ecol. Evol. 11: 424-429.

Katzir N, Danin-Poleg Y, Tzuri G, Karchi Z, et al. (1996). Length polymorphism and homologies of microsatellites in several Cucurbitaceae species. Theor. Appl. Genet. 93: 1282-1290.

Kong Q, Xiang C, Yu Z, Zhang C, et al. (2007). Mining and charactering microsatellites in Cucumis melo expressed sequence tags from sequence database. Mol. Ecol. Notes 7: 281-283.

Laghetti G, Accogli R and Hammer K (2008). Different cucumber melon (Cucumis melo L.) races cultivated in Salento (Italy). Genet. Resour. Crop Evol. 55: 619-623.

Liu L, Kakihara F and Kato M (2004). Characterization of six varieties of Cucumis melo L. based on morphological and physiological characters, including shelf-life of fruit. Euphytica 135: 305-313.

López-Sesé AI, Staub JE, Katzir N and Gómez-Guillamón ML (2002). Estimation of between and within accessions variation in selected Spanish melon germplasm using RAPD and SSR markers to assess strategies for large collection evaluation. Euphytica 127: 41-51.

Mantel N (1967). The detection of disease clustering and a generalized regression approach. Cancer Res. 27: 209-220.

McCreight JD, Staub JE, Koppar NM and Srivastava UC (1993). Indo-US Cucumis germplasm expedition. HortScience 28: 492.

Mliki A, Staub JE, Sun ZY and Ghorbel A (2001). Genetic diversity in melon (Cucumis melo L.): an evaluation of African germplasm. Genet. Resour. Crop Evol. 48: 587-597.

Monforte AJ, Garcia-Mas J and Arus P (2003). Genetic variability in melon based on microsatellite variation. Plant Breed. 122: $153-157$.

Nakata E, Staub JE, López-Sesé AI and Katzir N (2005). Genetic diversity of Japanese melon cultivars (Cucumis melo L.) as assessed by random amplified polymorphic DNA and simple sequence repeat markers. Genet. Resour. Crop Evol. 52: 405-419.

Nuñez-Palenius HG, Gomez-Lim M, Ochoa-Alejo N, Grumet R, et al. (2008). Melon fruits: genetic diversity, physiology, and biotechnology features. Crit. Rev. Biotechnol. 28: 13-55.

Pitrat M, Chauvet C and Foury C (1999). Diversity, history and production of cultivated Cucurbits. Acta Hortic. 492: 21-28.

Pitrat M, Hanelt P and Hammer K (2000). Some comments on infraspecific classification of cultivars of melon. Acta Hortic. 510: 29-36.

Powell W, Machray GC and Provan J (1996). Polymorphism revealed by simple sequence repeats. Trends Plant Sci. 1: 215-222.

Robinson RW and Decker-Walters DS (1997). Cucurbits. CAB International, Oxon.

Rohlf FJ (1998). NTSYS-PC Numerical Taxonomy and Multivariate Analysis System. Version 2.00. Exeter software, Setauket.

Sari N and Solmaz I (2007). Fruit characterization of some Turkish melon genotypes. Acta Hortic. 731: 103-108.

Sensoy A, Büyükalaca S and Abak K (2007). Evaluation of genetic diversity in Turkish melons (Cucumis melo L.) based on phenotypic characters and RAPD markers. Genet. Resour. Crop Evol. 54: 1351-1365.

Silberstein L, Kovalski I, Huang R, Anagnostou K, et al. (1999). Molecular variation in melon (Cucumis melo L.) as revealed by RFLP and RAPD markers. Sci. Hort. 79: 101-111.

Solmaz I, Sari N, Yalçin Mendi Y, Aka-Kacar Y, et al. (2010). Characterization of some melon genotypes collected from Eastern and Central Anatolia Region of Turkey. Acta Hortic. 871: 187-196.

Staub JE, Danin-Poleg Y, Fazio G, Horejsi T, et al. (2000). Comparative analysis of cultivated melon groups (Cucumis melo L.) using random amplified polymorphic DNA and simple sequence repeat markers. Euphytica 115: 225-241.

Staub JE, Lopez-Sese AI and Fanourakis N (2004). Diversity among melon landraces (Cucumis melo L.) from Greece and their genetic relationships with other melon germplasm of diverse origins. Euphytica 136: 151-166. 
Stepansky A, Kovalski I and Perl-Treves R (1999). Intraspecific classification of melons (Cucumis melo L.) in view of their phenotypic and molecular variation. Plant. Syst. Evol. 217: 313-332.

Szabo Z, Gyulai G, Toth Z and Heszky L (2008). Morphological and molecular diversity of 47 melon (Cucumis melo) cultivars compared to an extinct landrace excavated from the 15th century (Pihat M, ed.). Proceedings of the IXth Eucarpia Meeting on Genetics and Breeding of Cucurbitaceae, Avignon, 313-321.

Szamosi C, Solmaz I, Sari N and Bársony C (2010). Morphological evaluation and comparison of Hungarian and Turkish melon (Cucumis melo L.) germplasm. Sci. Hortic. 124: 170-182.

Tanaka K, Nishitani A, Akashi Y, Nishida H, et al. (2007). Molecular characterization of South and East Asian melon, Cucumis melo L., and the origin of group conomon var. makuwa and var. conomon revealed by RAPD analysis. Euphytica 153: 233-247.

Tzitzikas NE, Monforte AJ, Fatihi A, Kypriotakis Z, et al. (2009). Genetic diversity and population structure of traditional Greek and Cypriot melon cultigens (Cucumis melo L) based on simple sequence repeat variability. HortScience 44: $1820-1824$.

Zheng XY, Wolff DW, Baudracco-Arnas S and Pitrat M (1999). Development and utility of cleaved amplified polymorphic sequences (CAPS) and restriction fragment length polymorphisms (RFLPs) linked to the Fom-2 Fusarium wilt resistance gene in melon (Cucumis melo L.). Theor. Appl. Genet. 99: 453-463. 